\title{
Comparative Studies of Physico-Chemical Properties of the Roadside Soil at Morena (M.P.)
}

\author{
V.K. JAIN, V.K. GUPTA and LAXMI KANT SHARMA \\ Department of Chemistry, Ambah P.G. (Autonomous) College-Ambah, Morena M.P.,(476111), India. \\ http://dx.doi.org/10.12944/CWE.9.1.32
}

(Received: December 02, 2013; Accepted: January 06, 2014)

\begin{abstract}
The quality of roadside soil along the $\mathrm{NH} 3$ highway of high traffic density at Morena- M.P. was studied during 2010-11 at 12 different locations. The roadside soil was found to be highly contaminated. This is evident from the modification of the soil $\mathrm{pH}$, Electrical conductance, Water holding capacity and other Physico-chemical properties when compared to natural soil. The presence of heavy metals like $\mathrm{Zn}, \mathrm{Cu}, \mathrm{Mn}, \mathrm{Fe}$ in the roadside soil was also considerable.
\end{abstract}

Key words: Roadside Physicochemical properties of soil , Vehicle contaminants, Morena, India.

\section{INTRODUCTION}

Around the world the transport sector, which includes automobiles, trucks, trains, ships and aeroplanes is contributing ever increasing shares of the total air pollution burden. The pollution of soils by heavy metals from automobile sources is a serious environmental issue. Results show that roadside soil near motorways is heavily polluted by heavy metals from automobiles ${ }^{1-2}$. Changes in the composition of the urban atmosphere are caused largely by traffic induced pollutants ${ }^{3}$ mainly carbon monoxide, nitrogen monoxide, dust and as well as various types of non methane hydrocarbons, in particular benzene, toluene and xylene. Secondary trace gases which can be formed from these precursor substances in certain photochemical reactions. The soil and the shrubs near the road are immediate receptors of the contaminants generated by plying of various types of vechicles through exhaust emission and other processes. Vehicular emission are known as the single most important contributor to the atmospheric pollution. The vehicle associates components constitute nearly $70 \%$ of the contaminants input to roadside soil ${ }^{4}$, the rest of the input being from surface binders used in road constructions, dust fall and precipitation, road surface erosion, animal wasts and vegetable debris etc. Vehicular emission and evaporative emissions contents may contain unburnt hydrocarbons including polycyclic hydrocarbons and trace metals like $\mathrm{Pb}, \mathrm{Cd}, \mathrm{Zn}, \mathrm{Cu}$, $\mathrm{Mn}$ and $\mathrm{Fe}$ etc. The retention of various contaminants by the soil results in modification of its physio-chemical characteristics such as $\mathrm{pH}$, conductance, texture etc ${ }^{5}$. Thus it is expected that the roadside soil has a high degree of contamination \& its quality is a definitive indicator of vehicular pollution.

The location of Morena city is between the two important and historical cities Agra and Gwalior by national highway $\mathrm{NH} 3$. The quality of roadside soil along the major roads of known high traffic density of Morena will be studies of different location. The present study is a modest attempt to understand the impact of vehicular emission on the city roadside soil. For this purpose physico-chemical characteristics of the roadside soil samples were studies carefully during 2010-11. 


\section{MATERIALS AND METHODS}

Surface soil samples were collected from the roadside at 12 locations in high traffic density areas of Morena city. A set of samples was also taken from a zero traffic zone for comparison and correlation purposes. The sampling locations with distance and direction from the reference point (Agriculture-Center Morena) are given in Table 1. The reference point is atleast $4 \mathrm{~km}$ away from all forms of traffic is therefore considered as "Control". The samples were analysed for a no. of physical and chemical parameters as per standard procedure ${ }^{6-7}$.

\section{RESULTS AND DISCUSSION}

The results of the analysis are presented in Table 2. The values represent averages of at least three measurements.

The $\mathrm{pH}$ of the roadside soil (Table 2) was on the alkaline side (with the range 7.4 to 7.6 at 50 feet distance at the roadside) and (7.6 to 8.2 at 0 feet distance at the roadside) and was more than that of the control soil (6.7). The normally acidic soil has turned alkaline due to contamination. The electrical conductivity values were also slightly higher than that of the control $(0.10)$, indicating the input of some soluble electrolytes to the roadside

Table 1: The Sampling Location with distance from the reference point

\begin{tabular}{cc}
\hline S.N. Location & $\begin{array}{c}\text { Distance from control } \\
(\mathrm{Km}) / D i r e c t i o n\end{array}$
\end{tabular}

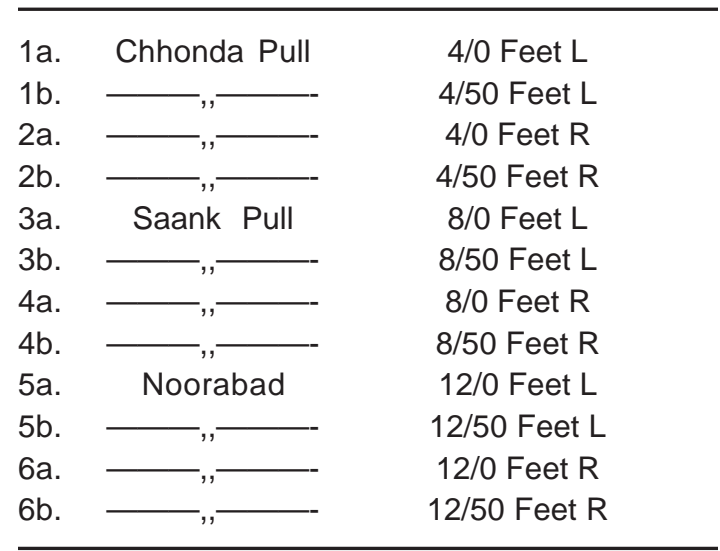

Table 2: Physicochemical Properties of Roadside Soil at Morena

\begin{tabular}{|c|c|c|c|c|c|c|c|c|c|c|c|c|c|c|}
\hline \multirow[b]{2}{*}{$\begin{array}{l}\text { S. } \\
\text { No }\end{array}$} & \multicolumn{2}{|r|}{$\mathrm{pH}$} & \multicolumn{2}{|c|}{ EC } & \multicolumn{2}{|c|}{ WHC } & \multicolumn{2}{|c|}{$\mathbf{N}$} & \multicolumn{2}{|c|}{$\mathbf{P}$} & \multicolumn{2}{|c|}{ K } & \multicolumn{2}{|c|}{$S$} \\
\hline & $\begin{array}{l}\overline{0_{L-R}} \\
\text { Feet }\end{array}$ & $\begin{array}{c}50_{L-R} \\
\text { Feet }\end{array}$ & $\begin{array}{l}0_{L-R} \\
\text { Feet }\end{array}$ & $\begin{array}{l}\overline{50}_{\mathrm{L}-\mathrm{R}} \\
\text { Feet }\end{array}$ & $\begin{array}{r}0_{L-R} \\
\text { Feet }\end{array}$ & $\begin{array}{l}50_{\mathrm{L}-\mathrm{R}} \\
\text { Feet }\end{array}$ & $\begin{array}{c}0_{L-R} \\
\text { Feet }\end{array}$ & $\begin{array}{l}5_{L-R} \\
\text { Feet }\end{array}$ & $\begin{array}{l}0_{L-R} \\
\text { Feet }\end{array}$ & $\begin{array}{l}50_{\mathrm{L}-\mathrm{R}} \\
\text { Feet }\end{array}$ & $\begin{array}{l}0_{L-R} \\
\text { Feet }\end{array}$ & $\begin{array}{l}50_{\mathrm{L}-\mathrm{R}} \\
\text { Feet }\end{array}$ & $\begin{array}{l}0_{L-R} \\
\text { Feet }\end{array}$ & $\begin{array}{l}\overline{50_{L-R}} \\
\text { Feet }\end{array}$ \\
\hline 1. & 7.6 & 7.4 & 0.21 & 0.19 & 6.71 & 39.12 & 266.2 & 118.7 & 15.6 & 10.0 & 314.0 & 284.7 & 16.3 & 11.7 \\
\hline 2. & 7.9 & 7.4 & 0.26 & 0.21 & 49.26 & 36.28 & 217.5 & 213.7 & 18.2 & 17.8 & 435.3 & 212.1 & 12.8 & 9.4 \\
\hline 3. & 7.8 & 7.5 & 0.31 & 0.22 & 48.06 & 46.60 & 239.5 & 232.0 & 10.9 & 10.7 & 309.0 & 303.0 & 23.4 & 13.2 \\
\hline 4. & 8.2 & 7.6 & 0.32 & 0.22 & 60.78 & 56.08 & 260.0 & 230.0 & 12.4 & 11.2 & 360.6 & 340.0 & 9.3 & 8.6 \\
\hline 5. & 8.0 & 7.4 & 0.28 & 0.21 & 59.18 & 50.16 & 269.5 & 262.5 & 11.2 & 9.2 & 463.9 & 374.7 & 15.2 & 13.4 \\
\hline 6. & 7.8 & 7.5 & 0.30 & 0.21 & 52.28 & 51.60 & 280.0 & 240.0 & 19.9 & 12.2 & 425.4 & 280.10 & 17.6 & 11.2 \\
\hline
\end{tabular}

Table 3: Physicochemical properties of Roadside Soil at Morena

\begin{tabular}{|c|c|c|c|c|c|c|c|c|}
\hline \multirow[b]{2}{*}{$\begin{array}{l}\text { S. } \\
\text { No }\end{array}$} & \multicolumn{2}{|c|}{$\mathrm{Zn}$} & \multicolumn{2}{|c|}{$\mathrm{Cu}$} & \multicolumn{2}{|c|}{$\mathrm{Mn}$} & \multicolumn{2}{|c|}{$\mathrm{Fe}$} \\
\hline & $\begin{array}{l}0_{L-R} \\
\text { Feet }\end{array}$ & $\begin{array}{l}5_{L-R} \\
\text { Feet }\end{array}$ & $\begin{array}{c}\overline{0_{L-R}} \\
\text { Feet }\end{array}$ & $\begin{array}{l}50_{\mathrm{L}-\mathrm{R}} \\
\text { Feet }\end{array}$ & $\begin{array}{l}0_{\text {L-R }} \\
\text { Feet }\end{array}$ & $\begin{array}{l}50_{L-R} \\
\text { Feet }\end{array}$ & $\begin{array}{l}0_{\text {L-R }} \\
\text { Feet }\end{array}$ & $\begin{array}{l}50_{L-R} \\
\text { Feet }\end{array}$ \\
\hline 1 & 3.06 & 2.02 & 15.8 & 8.40 & 65.16 & 47.42 & 15.8 & 8.40 \\
\hline 2 & 3.1 & 1.06 & 18.5 & 8.70 & 61.9 & 46.96 & 18.5 & 9.62 \\
\hline 3 & 2.88 & 1.08 & 6.25 & 4.62 & 27.96 & 16.50 & 4.62 & 2.25 \\
\hline 4 & 2.12 & 1.20 & 6.6 & 4.2 & 27.4 & 15.16 & 6.6 & 4.22 \\
\hline 5 & 2.70 & 2.0 & 5.46 & 3.66 & 29.08 & 17.44 & 5.46 & 3.65 \\
\hline 6 & 3.26 & 1.24 & 6.16 & 4.94 & 39.38 & 24.84 & 6.16 & 4.94 \\
\hline
\end{tabular}


soil due to various traffic related activities. Water holding capacity values (40-60\%) for 0 feet distance and (35-65\%) for 50 feet distance are lower than the control $(72 \%)$. Presence of hydrophobic matter often reduces water holding capacity and the results have indicated the entry of foreign matter to the roadside soil impairing its quality.

The values of $\mathrm{N}, \mathrm{P}, \mathrm{K}$, and $\mathrm{S}$ are estimated in all the roadside soil samples described in Table No. 2 and Table No. 3 described the values of heavy metals $\mathrm{Zn}, \mathrm{Cu}, \mathrm{Mn}$, and $\mathrm{Fe}$ of soil samples.

\section{CONCLUSION}

The present study shows conclusively that three is a large input of contaminants from vehicular emission and associated activities to the roadside soil. These inputs impair the quality of the soil nearby reducing its capacity to support plant life. While there may be some amount of favourable impact due to a few contributions, most other contaminants interfere with the natural properties of soil. Input of heavy metals on roadside plant leaf and entry of toxic organics such as the polyaromatic hydrocarbons are under investigation.

\section{REFERENCES}

1. Moller, H.W. Muller, A. Abdullah, G. Abdel Gawad and J. Ultermann, Urban soil pollution in Damascus, (2005).

2. Al-Khashman, O.A., The investigationof metal concentrations in street dust samples in Aqaba city, Jordan. Environ. Geochem. Health, 29: 197-207, (2007).

3. Al-Shayeb S.M. Metals content of roadside soils in Riyadh (Saudi Arabia), with particular reference to traffic density. Asian Journal of Chemistry, 15(3 \& 4), 1229-1245, (2003).

4. Dierkes C. And Geiger W.F. Pollutant retention capacity of roadside soils. Wasserwirtschaft, 90(6), 276-278, 280-281, (2000).

5. E.S. Abechi, O.J. Okunola, S.M.J. Zubairu, A.A. Usman, and E. Apene, Journal of Environmental Chemistry and Ecotoxicity, 98-102, (2010).
6. Fatoki O.S. Trace zinc and copper in roadside vegetation and soil in Alice, Eastern Cape, as monitor of atmospheric pollution. South African Journal of Science, 93(5), 240-242, (1997).

7. Goswami B.S. and Bhattacharya K.G. Changes in Roadside Soil Quality Due to Deposition of Vehicle Related Contaminants. Proc. XI National Symposium on Environment, 165-169, (2002).

8. L.J. Evans, Environ. Sci. Technol, 23, 1046, 1989. M.L. Jackson, Soil Chemical Analysis, Prentice- Hall (India), New Delhi, (1967).

9. P.C. Onianwa and J.O. Adoghe, Environment International, 23: 873-877 (1997).

10. T.C. Baruah and H.P. Borthakur, A Textbook of Soil Chemical Analysis, Vikas Publishing, New Delhi, (1967). 